\section{Cureus}

\title{
Subthalamic and Pallidal Deep Brain Stimulation for Parkinson's Disease
}

\author{
Ahmed Negida ${ }^{1}$, Mohamed Elminawy ${ }^{2}$, Gehad El Ashal ${ }^{3}$, Ahmed Essam ${ }^{4}$, Athar Eysa ${ }^{5}$, \\ Mohamed Abd Elalem Aziz ${ }^{6}$ \\ 1. Faculty of Medicine, Zagazig University, Zagazig, EGY 2. Department of Neurological Surgery, Mayo \\ Clinic, Rochester, MN, USA 3. Faculty of Medicine, Cairo University 4. Faculty of Medicine, Beni-Suef \\ University 5. Faculty of Medicine, Menoufia University 6. Psychiatry, Amr Shahin Mental Hospital, \\ Cairo, EGY
}

$\square$ Corresponding author: Mohamed Abd Elalem Aziz, mohamedabdelalem@med.menofia.edu.eg Disclosures can be found in Additional Information at the end of the article

\section{Abstract}

Deep brain stimulation (DBS) is a surgical treatment in which stimulation electrodes are permanently implanted in basal ganglia to treat motor fluctuations and symptoms of Parkinson's disease (PD). Subthalamic nucleus (STN) and globus pallidus internus (GPi) are the commonly used targets for DBS in PD. Many studies have compared motor and non-motor outcomes of DBS in both targets. However, the selection of PD patients for DBS targets is still poorly studied. Therefore, we performed this narrative review to summarize published studies comparing STN DBS and GPi DBS. GPi DBS is better for patients with problems in speech, mood, or cognition while STN DBS is better from an economic point of view as it allows much reduction in antiparkinson medications and less battery consumption.

Categories: Neurology

Keywords: deep brain stimulation, parkinson's disease, subthalamic nucleus, globus pallidus internus, motor function

\section{Introduction And Background}

Parkinson's disease (PD) is a motor disorder characterized by progressive degeneration of dopaminergic neurons in the basal ganglia (BG). This degeneration causes overactivity of subthalamic nucleus (STN) leading to increased globus pallidus internus (GPi) output, which causes PD symptoms. PD is associated with several motor symptoms (rigidity, bradykinesia, postural instability, and tremors) and non-motor symptoms (cognitive problems, dementia, and depression). The etiology of PD is unknown and there is no cure for it. Current symptomatic treatments aim at controlling PD symptoms and improving patients' quality of life.

Pharmacological treatments enhance the dopaminergic action in the BG. Therefore, they reduce PD symptoms that are mainly due to lack of dopamine. Levodopa (LD) is a widely used pharmacological treatment that induces the conversion of L-DOPA to dopamine by DOPA decarboxylase enzyme in dopaminergic neurons. However, there are two problems with pharmacological treatment: 1 ) the wearing-off phenomenon in which the duration of action of the drug decreases gradually over time, so patients experience severe PD symptoms between drug intervals, and 2) pharmacological treatment is not effective in all patients; some patients are refractory. Due to the limitations of pharmacological treatments, investigators have developed surgical treatments as pallidotomy, thalamotomy, and deep brain stimulation to overcome the failure of pharmacological treatments. 


\section{Cureus}

Deep brain stimulation is a surgical treatment for various neurological disorders. In DBS surgery, electrical stimulation is transmitted to the target site via the implanted electrode. To present, the mechanism of action of DBS is not clear. It is suggested that DBS acts via a depolarization blockade mechanism, releasing local inhibitory neurotransmitters and activating inhibitory neurons that antagonize the effect of dopamine. Therefore, DBS acts through restoring balance in the chemical composition of BG, which decreases motor fluctuations and alleviates PD symptoms. DBS has been widely used because it is reversible and stimulation parameters can be adjusted for each patient by their neurologist. According to Medtronic Inc., about 70,000 patients have undergone DBS surgery between 2002 and 2011 [1]. Subthalamic nucleus (STN) and globus pallidus internus (GPi) are the commonly used targets for DBS in PD.

Many studies have compared motor and non-motor outcomes of DBS in both targets. However, the selection of patients for DBS targets was poorly studied. There is a need to summarize the available evidence to help neurologists select patients for DBS targets. Therefore, we performed this narrative review to summarize published meta-analyses and randomized controlled trials (RCTs) comparing STN DBS and GPi DBS. Table 1 and Table 2 show the design, sample size, and main findings of RCTs comparing STN DBS and GPi DBS. Table 3 summarizes the findings of two meta-analyses directly comparing STN DBS and GPi DBS.

\begin{tabular}{|c|c|c|c|c|c|}
\hline $\begin{array}{l}\text { Study ID } \\
\text { and year }\end{array}$ & Design & & $\begin{array}{l}\text { Sample } \\
\text { size }\end{array}$ & Intervention & Main findings \\
\hline $\begin{array}{l}\text { George et } \\
\text { al. [2] } \\
(2014)\end{array}$ & $\begin{array}{l}\text { Double } \\
\text { blind } \\
\text { randomized } \\
\text { trial }\end{array}$ & Parallel & $\begin{array}{l}37 \\
\text { patients } \\
\text { with PD } \\
\text { (nine } \\
\text { patients } \\
\text { were } \\
\text { control } \\
\text { without } \\
\text { DBS) }\end{array}$ & $\begin{array}{l}\text { Bilateral } \\
\text { subthalamic } \\
\text { or pallidal } \\
\text { DBS }\end{array}$ & $\begin{array}{l}\text { STN DBS and GPi DBS had similar effects on the } \\
\text { balance and gait of PD subjects. There were some } \\
\text { indicators that GPi DBS may be preferable over STN in } \\
\text { PD patients with stability concerns. }\end{array}$ \\
\hline $\begin{array}{l}\text { Odekerken } \\
\text { et al. [3] } \\
(2013)\end{array}$ & $\mathrm{RCT}$ & Parallel & $\begin{array}{l}128 \\
\text { patients } \\
\text { with PD }\end{array}$ & $\begin{array}{l}\text { Bilateral } \\
\text { subthalamic } \\
\text { or pallidal } \\
\text { DBS }\end{array}$ & $\begin{array}{l}\text { There was no significant difference in motor functions } \\
\text { between the two groups. GPi DBS reduced dyskinesia } \\
\text { more than STN DBS in case of giving the same } \\
\text { levodopa equivalent dose (LED). However, STN DBS } \\
\text { allowed reduction in LED more than GPi DBS so STN } \\
\text { DBS patients might experience less dyskinesia than } \\
\text { expected. }\end{array}$ \\
\hline $\begin{array}{l}\text { Follet et al. } \\
\text { [4] (2010) }\end{array}$ & RCT & Parallel & $\begin{array}{l}299 \\
\text { patients } \\
\text { with PD }\end{array}$ & $\begin{array}{l}\text { Bilateral } \\
\text { subthalamic } \\
\text { or pallidal } \\
\text { DBS }\end{array}$ & $\begin{array}{l}\text { There was no significant difference in motor function } \\
\text { improvement between the two groups at } 24 \text { months. } \\
\text { Also, no significant difference in Qol between the two } \\
\text { groups. Neurocognitive and mood outcomes were better } \\
\text { in GPi DBS group than STN DBS group and the authors } \\
\text { suggested that STN is a better target for DBS than GPi. }\end{array}$ \\
\hline
\end{tabular}

Two-thirds of participants 


\section{Cureus}

\begin{tabular}{|c|c|c|c|c|}
\hline $\begin{array}{l}\text { Jones et al. } \\
\text { [5] (2010) }\end{array}$ & RCT & $\begin{array}{l}\text { Cross } \\
\text { over }\end{array}$ & $\begin{array}{l}12 \\
\text { patients } \\
\text { with PD }\end{array}$ & $\begin{array}{l}(8 / 12) \text { had } \\
\text { unilateral } \\
\text { DBS and } \\
\text { one-third } \\
(4 / 12) \text { had } \\
\text { bilateral DBS }\end{array}$ \\
\hline $\begin{array}{l}\text { COMPARE } \\
\text { trial [6] } \\
(2009)\end{array}$ & RCT & Parallel & $\begin{array}{l}52 \\
\text { patients } \\
\text { with PD }\end{array}$ & $\begin{array}{l}\text { Unilateral } \\
\text { subthalamic } \\
\text { or pallidal } \\
\text { DBS }\end{array}$ \\
\hline
\end{tabular}

Rothlind et al. [7] RCT (2007)

Nakamura et al. [8] RCT (2007)

Anderson et al. [9] (2005)

Burchiel et al. [10] (1999)
RCT
RCT

$\begin{array}{ll}\text { Cross } & 23 \\ \text { over } & \text { patients } \\ & \text { with PD }\end{array}$

10

Parallel patients

\section{Staged}

bilateral

subthalamic

or pallidal

DBS

Unilateral subthalamic or pallidal DBS

Bilateral subthalamic or pallidal DBS

Bilateral subthalamic or pallidal DBS
There was no statistically significant difference between STN DBS and GPi DBS in terms of speech reaction time.

There was no significant difference between STN DBS and GPi DBS in mood and cognition. STN DBS group showed larger deterioration in verbal fluency scores than GPi DBS especially in the off-medication state and no significant difference in UPDRS motor score between the two groups.

STN DBS was associated with small reduction in speed of information processing and memory. Both bilateral and unilateral DBS were associated with small but significant reduction in neuropsychological performance. Declines in semantic verbal fluency were associated with left-sided treatment.

STN and GPi resulted in similar improvement in hand movements at short term follow-up. Preoperative medication responsiveness predicted improvement in some motor tasks.

UPDRS scores improved; there was no difference between STN DBS and GPi DBS. Bradykinesia improved better in STN DBS group but ADL did not improve by DBS further than medication.

Both STN DBS and GPi DBS had no significant difference in improvement of UPDRS III motor score during on and off medication conditions. Chronic stimulation of GPi DBS might improve symptoms in combination with LD more than chronic LD/STN stimulation. STN DBS was associated with greater reduction in antiparkinson drugs.

\section{TABLE 1: Summary of design and conclusions of RCTs comparing STN DBS and GPi DBS.}

$\mathrm{RCT}=$ Randomized controlled trial, DBS= Deep brain stimulation, STN= Subthalamic nucleus, GPi= Globus pallidus internus, $\mathrm{PD}=$ Parkinson's disease, $\mathrm{BDI}=$ Beck depression inventory, UPDRS $=$ Unified Parkinson disease rating scale, Qol= Quality of life, $\mathrm{ADL}=$ Activities of daily life, $L D=$ Levodopa.

\begin{tabular}{|l|l|l|l|}
\hline Study ID & Design & $\begin{array}{l}\text { Sample } \\
\text { size }\end{array}$ & $\begin{array}{l}\text { Intervention } \\
\text { Main findings }\end{array}$ \\
\hline & & There was no significant difference between GPi DBS \\
\hline
\end{tabular}




\section{Cureus}

\begin{tabular}{|c|c|c|c|c|c|}
\hline $\begin{array}{l}\text { Katz et al. } \\
{[11](2015)}\end{array}$ & $\begin{array}{l}\text { Cohort from } \\
\text { multicenter } \\
\text { RCT (Follet } \\
\text { et al. [4] } \\
2010 \text { ) }\end{array}$ & Parallel & $\begin{array}{l}235 \\
\text { patients } \\
\text { with PD }\end{array}$ & $\begin{array}{l}\text { Bilateral } \\
\text { subthalamic } \\
\text { or pallidal } \\
\text { DBS }\end{array}$ & $\begin{array}{l}\text { and STN DBS among different PD motor subtypes. } \\
\text { Tremor dominant (TD) motor subtype had significantly } \\
\text { greater response to GPi DBS with respect to gait. } \\
\text { Postural instability gait difficulty (PIGD) patients } \\
\text { obtained the least benefit from both GPi DBS and STN } \\
\text { DBS. }\end{array}$ \\
\hline $\begin{array}{l}\text { Odekerken } \\
\text { et al. [12] } \\
(2015)\end{array}$ & $\begin{array}{l}\text { Cohort from } \\
\text { (Odekerken } \\
\text { et al. [3] } \\
\text { 2013) }\end{array}$ & Parallel & $\begin{array}{l}114 \\
\text { patients } \\
\text { with PD }\end{array}$ & $\begin{array}{l}\text { Bilateral } \\
\text { subthalamic } \\
\text { or pallidal } \\
\text { DBS }\end{array}$ & $\begin{array}{l}\text { There was no significant difference in } \\
\text { neuropsychological outcome between STN DBS and } \\
\text { GPI DBS. STN DBS showed greater negative change } \\
\text { than GPi DBs in mental speed, attention, and language. }\end{array}$ \\
\hline $\begin{array}{l}\text { Rothlind et } \\
\text { al. [13] } \\
(2015)\end{array}$ & $\begin{array}{l}\text { Cohort from } \\
\text { multicenter } \\
\text { RCT (Weaver } \\
\text { et al. [14] } \\
\text { 2009) }\end{array}$ & Parallel & $\begin{array}{l}281 \\
\text { patient } \\
\text { with PD }\end{array}$ & $\begin{array}{l}\text { Bilateral } \\
\text { subthalamic } \\
\text { or pallidal } \\
\text { DBS }\end{array}$ & $\begin{array}{l}\text { Few isolated significant neuropsychological changes } \\
\text { were detected among STN DBS and GPi DBS groups. } \\
\text { There was slightly greater reduction in processing speed } \\
\text { after STN DBS than GPi DBS. STN DBS showed a } \\
\text { greater reduction in verbal learning and recall } \\
\text { performance than GPi DBS. }\end{array}$ \\
\hline $\begin{array}{l}\text { Weintraub } \\
\text { et al. [15] } \\
2013\end{array}$ & $\begin{array}{l}\text { RCT (Follet } \\
\text { et al. [4] } \\
2010)\end{array}$ & Parallel & $\begin{array}{l}299 \\
\text { patient } \\
\text { with PD }\end{array}$ & $\begin{array}{l}\text { Bilateral } \\
\text { subthalamic } \\
\text { or pallidal } \\
\text { DBS }\end{array}$ & $\begin{array}{l}\text { There was no difference between STN DBS and GPi } \\
\text { DBS in terms of suicide ideation and behaviors (after } 24 \\
\text { months follow-up). }\end{array}$ \\
\hline $\begin{array}{l}\text { Dietz et al. } \\
{[16](2013)}\end{array}$ & $\begin{array}{l}\text { Cohort from } \\
\text { COMPARE } \\
\text { trial }[6]\end{array}$ & Parallel & $\begin{array}{l}14 \\
\text { patients } \\
\text { with PD }\end{array}$ & $\begin{array}{l}\text { Unilateral } \\
\text { subthalamic } \\
\text { or pallidal } \\
\text { DBS }\end{array}$ & $\begin{array}{l}\text { GBi DBS there showed no significant change in verbal } \\
\text { fluency performance between different stimulation } \\
\text { locations (optimal, ventral, and dorsal) in contrast to } \\
\text { (Mikos et al. [17]) findings with STN DBS patients. }\end{array}$ \\
\hline $\begin{array}{l}\text { Rocchi et } \\
\text { al. [18] } \\
(2012)\end{array}$ & $\begin{array}{l}\text { Cohort from } \\
\text { multicenter } \\
\text { RCT } \\
\text { (Weaver et } \\
\text { al. [14] 2009) }\end{array}$ & Parallel & $\begin{array}{l}29 \\
\text { Patients } \\
\text { with PD }\end{array}$ & $\begin{array}{l}\text { Bilateral } \\
\text { subthalamic } \\
\text { or pallidal } \\
\text { DBS }\end{array}$ & $\begin{array}{l}\text { There was no significant difference in anticipatory } \\
\text { postural adjustment (APA) between the two groups. }\end{array}$ \\
\hline $\begin{array}{l}\text { Weaver et } \\
\text { al. [19] } \\
(2012)\end{array}$ & $\begin{array}{l}\text { RCT subset } \\
\text { from Weaver } \\
\text { et al. [14] } \\
\text { 2009) }\end{array}$ & Parallel & $\begin{array}{l}159 \\
\text { patients } \\
\text { with PD }\end{array}$ & $\begin{array}{l}\text { Bilateral } \\
\text { subthalamic } \\
\text { or pallidal } \\
\text { DBS }\end{array}$ & $\begin{array}{l}\text { Motor function improvements were similar and } \\
\text { statistically significant for both STN DBS and GPi DBS } \\
\text { groups at } 36 \text { months post surgery but showed decline } \\
\text { over time (decline was faster in STN group than GPi } \\
\text { group). Qol scale improved at six months but diminished } \\
\text { over time. Emotional well-being, social support, and } \\
\text { cognition subscales showed no difference over time. } \\
\text { Activities of daily living showed early improvement after } \\
\text { surgery followed by gradual loss of improvement over } \\
\text { the subsequent assessments. Mattis Dementia Rating } \\
\text { Scale and the Hopkins Verbal Learning Test scores } \\
\text { declined faster for STN than GPi patients by } 36 \text { months. }\end{array}$ \\
\hline $\begin{array}{l}\text { Locke et } \\
\text { al. [20] } \\
(2011)\end{array}$ & $\begin{array}{l}\text { Retrospective } \\
\text { cohort from } \\
\text { COMPARE } \\
\text { trial [6] }\end{array}$ & Parallel & $\begin{array}{l}44 \\
\text { patients } \\
\text { with PD }\end{array}$ & $\begin{array}{l}\text { Unilateral } \\
\text { subthalamic } \\
\text { or pallidal } \\
\text { DBS }\end{array}$ & $\begin{array}{l}\text { DBS is associated with weight gain with no significant } \\
\text { difference between STN DBS and GPi DBS. }\end{array}$ \\
\hline
\end{tabular}




\section{Cureus}

\begin{tabular}{|c|c|c|c|c|c|}
\hline $\begin{array}{l}\text { Mikos et } \\
\text { al. [17] } \\
(2011)\end{array}$ & $\begin{array}{l}\text { Cohort from } \\
\text { COMPARE } \\
\text { trial }[6]\end{array}$ & Parallel & $\begin{array}{l}17 \\
\text { patients } \\
\text { with PD }\end{array}$ & $\begin{array}{l}\text { Unilateral } \\
\text { subthalamic } \\
\text { or pallidal } \\
\text { DBS }\end{array}$ & $\begin{array}{l}\text { STN DBS was associated with decreased letter fluency } \\
\text { performance at ventral contacts whereas in optimal } \\
\text { contacts STN DBS was associated with improved letter } \\
\text { fluency performance. }\end{array}$ \\
\hline $\begin{array}{l}\text { Robertson } \\
\text { et al. [21] } \\
(2011)\end{array}$ & $\begin{array}{l}\text { Cohort from } \\
\text { multicenter } \\
\text { RCT (Follet } \\
\text { et al. [4] } \\
\text { 2010) }\end{array}$ & Parallel & $\begin{array}{l}27 \\
\text { patients } \\
\text { with PD }\end{array}$ & $\begin{array}{l}\text { Bilateral } \\
\text { subthalamic } \\
\text { or pallidal } \\
\text { DBS }\end{array}$ & $\begin{array}{l}\text { There was a significant improvement in jaw velocity in } \\
\text { GPi DBS patients. STN DBS patients had a } \\
\text { significantly worse jaw velocity six months after surgery. }\end{array}$ \\
\hline $\begin{array}{l}\text { Taba et al. } \\
\text { [22] (2010) }\end{array}$ & $\begin{array}{l}\text { Cohort from } \\
\text { COMPARE } \\
\text { trial }[6]\end{array}$ & Parallel & $\begin{array}{l}44 \\
\text { patients } \\
\text { with PD }\end{array}$ & $\begin{array}{l}\text { Unilateral } \\
\text { subthalamic } \\
\text { or pallidal } \\
\text { DBS }\end{array}$ & $\begin{array}{l}\text { Patients with GPi DBS were more likely to choose to } \\
\text { remain with unilateral implantation. The logistic } \\
\text { regression analysis revealed that the odds of proceeding } \\
\text { to bilateral DBS were } 5.2 \text { times higher for STN DBS than } \\
\text { for GPi DBS. }\end{array}$ \\
\hline $\begin{array}{l}\text { Zahodne } \\
\text { et al. [23] } \\
\text { (2009) }\end{array}$ & $\begin{array}{l}\text { Cohort from } \\
\text { COMPARE } \\
\text { trial }[6]\end{array}$ & Parallel & $\begin{array}{l}42 \\
\text { patients } \\
\text { with PD }\end{array}$ & $\begin{array}{l}\text { Unilateral } \\
\text { subthalamic } \\
\text { or pallidal } \\
\text { DBS }\end{array}$ & $\begin{array}{l}\text { Unilateral DBS in both STN and GPi improved overall } \\
\text { Qol six months after surgery. GPi DBS reported greater } \\
\text { improvements in Qol. Verbal fluency problems } \\
\text { correlated with poorer Qol on the communication } \\
\text { subscale. }\end{array}$ \\
\hline $\begin{array}{l}\text { Rocchi et } \\
\text { al. [24] } \\
(2004)\end{array}$ & $\begin{array}{l}\text { RCT subset } \\
\text { from } \\
\text { (Burchiel et } \\
\text { al. [10] 1999) }\end{array}$ & Parallel & $\begin{array}{l}\text { Nine } \\
\text { patients } \\
\text { with PD }\end{array}$ & $\begin{array}{l}\text { Bilateral } \\
\text { subthalamic } \\
\text { or pallidal } \\
\text { DBS }\end{array}$ & $\begin{array}{l}\text { Levodopa had less negative side effects on posture in } \\
\text { patients with STN DBS than patients with GPi DBS. } \\
\text { UPDRS scores were higher in STN DBS patients than } \\
\text { GPi DBS in the off condition evident by worse motor } \\
\text { signs in STN DBS patients. All center of pressure (CoP) } \\
\text { parameters showed deterioration of postural control with } \\
\text { DOPA for both the STN DBS and GPi DBS. In on- } \\
\text { treatment condition, Cop values were close to normal in } \\
\text { STN than GPi. Although, STN groups were more } \\
\text { affected by PD. It is suggested that levodopa } \\
\text { replacement was more effective for posture in STN DBS } \\
\text { group than GPi group. }\end{array}$ \\
\hline
\end{tabular}

\section{TABLE 2: Summary of design and conclusions of studies on cohort populations from RCTs mentioned in the first table.}

Summary of design and conclusions of studies on cohort populations from RCTs mentioned in Table 1. RCT= Randomized controlled trial, DBS= Deep brain stimulation, STN= Subthalamic nucleus, GPi= Globus pallidus internus, $\mathrm{PD}=\mathrm{Parkinson}$ 's disease, $\mathrm{PIGD=}$ Postural instability gait difficulty, $T D=$ tremor dominant, $\mathrm{BDI}=$ Beck depression inventory, UPDRS= Unified Parkinson disease rating scale, Qol= Quality of life, $A D L=$ Activities of daily life, $L D=$ Levodopa, $C O P=$ Center of pressure. 


\section{Cureus}

\begin{tabular}{|c|c|c|c|}
\hline $\begin{array}{l}\text { Study } \\
\text { ID and } \\
\text { year }\end{array}$ & Design & $\begin{array}{l}\text { Sample } \\
\text { size }\end{array}$ & Main findings \\
\hline $\begin{array}{l}\text { Sako et } \\
\text { al. [25] } \\
(2014)\end{array}$ & $\begin{array}{l}\text { Meta- } \\
\text { analysis } \\
\text { of four } \\
\text { RCTs }\end{array}$ & $\begin{array}{l}\text { patients } \\
\text { with PD }\end{array}$ & $\begin{array}{l}\text { There was no significant difference between the two groups in improvement of UPDRS III } \\
\text { motor scores. Depression was associated with STN DBS group. }\end{array}$ \\
\hline $\begin{array}{l}\text { Liu et al. } \\
\text { [26] } \\
(2014)\end{array}$ & $\begin{array}{l}\text { Meta- } \\
\text { analysis } \\
\text { of six } \\
\text { RCTs }\end{array}$ & $\begin{array}{l}563 \\
\text { Patients } \\
\text { with PD }\end{array}$ & $\begin{array}{l}\text { There was no significant difference between STN DBS and GPi DBS in UPDRS III motor } \\
\text { score (on and off medication phases). Activities of daily life on UPDRS II (on medication } \\
\text { phase) did not favor either of the two groups. STN DBS was associated with greater } \\
\text { reduction in antiparkinson medications. Depression on BDI-II (Beck Depression } \\
\text { Inventory) score differed significantly favoring GPi DBS group. }\end{array}$ \\
\hline $\begin{array}{l}\text { Negida } \\
\text { et al. } \\
{[27]} \\
(2015)\end{array}$ & $\begin{array}{l}\text { Meta- } \\
\text { analysis } \\
\text { of nine } \\
\text { RCTs }\end{array}$ & $\begin{array}{l}497 \\
\text { patients } \\
\text { with PD }\end{array}$ & $\begin{array}{l}\text { There was no significant difference between STN DBS and GPi DBS in UPDRS III motor } \\
\text { score (on and off medication phases). Activities of daily life on UPDRS II (on medication } \\
\text { phase) did not favor either of the two groups. The levodopa equivalent dose was less in } \\
\text { patients undergoing STN DBS than GPi DBS. STN DBS allows more reduction in } \\
\text { medication than GPi DBS. Subthalmic and pallidal DBS achieved the same motor } \\
\text { improvement in PD patients. }\end{array}$ \\
\hline $\begin{array}{l}\text { Elgebaly } \\
\text { et al. } \\
\text { [28] } \\
(2017)\end{array}$ & $\begin{array}{l}\text { Meta- } \\
\text { analysis } \\
\text { of four } \\
\text { RCTs }\end{array}$ & $\begin{array}{l}345 \\
\text { patients } \\
\text { with PD }\end{array}$ & $\begin{array}{l}\text { There was no statistically significant difference between STN DBS and GPi DBS in } \\
\text { neuropsychological outcomes. }\end{array}$ \\
\hline $\begin{array}{l}\text { Negida } \\
\text { et al. } \\
\text { [29] } \\
(2017)\end{array}$ & $\begin{array}{l}\text { Meta- } \\
\text { analysis } \\
\text { of four } \\
\text { RCTs }\end{array}$ & $\begin{array}{l}479 \\
\text { patients } \\
\text { with PD }\end{array}$ & $\begin{array}{l}\text { Death was more common after STN DBS than GPi DBS in PD patients, most of deaths } \\
\text { due to postoperative complications. }\end{array}$ \\
\hline
\end{tabular}

\section{TABLE 3: Summary of key conclusions of meta-analyses comparing STN DBS and GPi DBS for PD.}

$\mathrm{RCT}=$ Randomized controlled trial, DBS= Deep brain stimulation, STN= Subthalamic nucleus, GPi= Globus pallidus internus, $\mathrm{PD}=$ Parkinson's disease, $\mathrm{BDI}=$ Beck depression inventory, UPDRS= Unified Parkinson disease rating scale.

\section{Review}

\section{Motor functions and PD motor symptoms}

There was no significant difference between STN DBS and GPi DBS in terms of the unified Parkinson's disease rating scale III (UPDRS III) motor score [3, 4, 6, 9-11, 19, 25, 26, 30]. The study of Rocchi et al. [24] was the only study where UPDRS scores were higher in STN DBS patients than in GPi DBS in the off condition evident by worse motor signs in STN DBS patients. In Odekerken et al. [3], STN DBS was associated with improvement in motor symptoms and disability in the off-phase than GPi DBS. However, in Follet et al. [4] and Anderson et al. [9], the GPi DBS group showed more improvement in UPDRS III score and stand-walk-sit times than STN DBS. These better motor scores in GPi DBS were consistent in the 36-month outcome [19]. The higher doses of medication in the GPi DBS group and the increase in stimulation washout 
time may justify this improvement in the GPi DBS group [4, 19].

In the study of George et al. [2], balance and gait did not differ significantly between the two groups. However, the authors concluded that some predictors make GPi DBS better than STN DBS for patients with stability concerns. In another study, postural instability gait difficulty (PIGD) patients obtained the least benefit from both GPi DBS and STN DBS [11] and tremor dominant (TD) motor subtype showed better response to GPi DBS with respect to gait [11]. Anticipatory postural adjustment (APA) did not differ significantly between the two targets in the study of Rocchi et al. [18]. In another study by Rocchi et al. [24] where they examined postural performance after STN DBS and GPi DBS, they found that levodopa had less negative side effects on posture in patients with STN DBS than GPi DBS. They suggested that levodopa treatment was more effective for posture in STN DBS than in GPi DBS.

Combining medication with stimulation gives better response in GPi DBS while STN DBS gives optimum benefit with much reduction in medication $[10,26]$. This suggests a possible synergistic effect between STN DBS and medications [3]. Although some reports described a decline in motor functions over time in case of STN DBS [19, 31, 32], in a large multicenter RCT by Follet et al. [4], there was no decline in motor functions in both STN DBS and GPi DBS groups after 24 months (Table 1).

\section{Activities of daily life and medication dose}

Activities of daily life (ADL) did not differ between the two groups in most studies. In unilateral implantation, GPi DBS was associated with higher ADL than STN DBS [6]. A gradual loss in improvement of ADL was noticed in both groups after the 36-month follow-up [19]. When patients received the same levodopa dose to induce the on-medication phase, the STN DBS group experienced more dyskinesia than the GPi DBS group [3]. When given the same levodopa equivalent dose (LED), patients with GPi DBS showed less dyskinesia than patients with STN DBS [3]. However, in the study of Moro et al. [9], STN DBS was likely to improve bradykinesia in the off-medication phase more than GPi DBS. However, most studies showed that STN DBS allowed significant reduction in $\operatorname{LED}[3,4,6,7,9,10,18,19,23,26]$ and so they have less dyskinesia. This makes STN a better target for PD patients from an economic point of view [33] and for whom a reduction of medication may be desirable [34].

Quality of life (Qol) improved in patients of both groups at six months but diminished over time. The study of Follet et al. [4], showed no significant difference in Qol between the two targets. But in another study by Zahodne et al. [23], GPi DBS showed better improvement in Qol than STN DBS. However, STN DBS has the advantage of reducing antiparkinsonian medications; this should also be taken into consideration because it may contribute to better quality of life (Qol) in some patients [4] (Table 2).

\section{Verbal fluency}

Left lateralized DBS was associated with worsening of the verbal fluency (VF) [7]. STN DBS was associated with worsening of letter verbal fluency after seven months [6]. However, GPi DBS was not associated with verbal fluency problems whatever the stimulation location within globus pallidus was [16]. Verbal fluency was not worsened in STN DBS when low frequency stimulation was used [35]. Getting more ventral in the stimulation location for STN DBS reduced VF [17]. No difference in speech reaction time was noted between both groups [5].

\section{Neuropsychological performance}

Self-reported depression was more common with STN DBS than GPi DBS [4, 7, 26]. However, in the 36-month outcome of the study by Follet et al. RCT [4], depression did not differ 
significantly between the two groups [19]. In the COMPARE trial [6], secondary outcomes revealed increased anger in the STN DBS group only; this anger was reported in previous STN DBS reports [36-38]. Anxiety was fairly common in the STN DBS group in the Anderson et al. study [9]. Visuomotor speed decreased significantly after STN DBS more than GPi DBS [4]. Because digital symbol performance is a task that requires visuomotor coordination, the decline in visuomotor speed after STN DBS justifies the decline in digital symbol performance after STN DBS in the Rothlind et al. RCT [7]. Dementia rating scale worsened more in the STN DBS group than GPi DBS [4, 19]. When Odekerken et al. [3] used a dichotomous composite measure instead of continuous standardized measure for cognition and mood, there was no statistically significant difference between the two groups (Table 2). Elgebaly et al. [28] also showed slight improvement among the GPi DBS group in terms of psychomotor speed and verbal fluency (Table 3).

The relative disturbance in cognition and mood, associated with the STN DBS group, can be justified by the greater possibility of suboptimal lead placement in the STN target. The STN target is smaller in architectural size than the GPi target ( $\sim 158 \mathrm{~mm} 3$ versus $\sim 478 \mathrm{~mm} 3$, respectively) [6] and the placement of the lead within STN may correlate with the stimulation of nearby fibers within limbic functions pathways [6, 7]. In the COMPARE trial [6], unilateral implantation did not show a significant difference in cognition and mood between the two targets. Higher baseline neurophysiological performance was associated with more decline in working memory and executive functioning after DBS [7].

\section{Adverse events}

Adverse events (AEs) of DBS are classified into five groups: 1) perioperative AEs: headache, anxiety, tension, restless, confusion, and hallucination [39-41]; 2) intraoperative AEs: vasovagal response, syncope, ischemic stroke, hypotension, arrhythmia, confusion, seizure, intracranial hemorrhage, intraventricular hemorrhage, and subdural hematoma [9, 39, 40]; 3) postoperative AEs: symptomatic and asymptomatic intracranial and intraventricular hemorrhage, ischemic infarction, lack of consciousness, and hemiparesis [39, 41]; 4) long term AEs: pain, dysarthria, cognitive dysfunction, paresthesia, and balance disorder [39]; 5) hardware-related complications requiring surgical revision: wound infection, lead migration, lead fracture, and lead malposition [39]. The total number of AEs reported in RCTs comparing STN DBS and GPi DBS was more in STN DBS than in GPi DBS [3, 4, 6, 9]. However, few of them were statistically significant. In the trial of Follet and colleagues [4] fall and depression were common AEs in the STN DBS group. Microelectrode passes were associated with an increased risk of intracranial bleeding [42] (Table 1).

In their meta-analysis, Sako et al. [25] reported that depression was significantly more common in the STN DBS group than in the GPi DBS group while other five AEs were not significant: 1 ) confusion/delirium, 2) intracranial hemorrhage, 3) dysarthria/speech problems, 4) balance disorder, 5) stroke/transient ischemic attack (TIA). In the other meta-analysis of Liu et al. [26], depression on the Beck Depression Inventory-II (BDI-II) score differs significantly favoring GPi DBS than STN DBS.

It has not escaped our notice that investigators of different studies used different definitions of AEs. There was no standardized definition or outcome measurement for AEs. Therefore, it is difficult to estimate these AEs in meta-analyses models. In their recent meta-analysis of depression and anxiety, Couto et al. [43] concluded that results of relevant clinical trials are heterogeneous. Therefore, standardization of outcome measurement is recommended across centers.

Negida et al. (2017) [29] also concluded death was more common after STN DBS than GPi DBS in PD patients, and most of the deaths were due to postoperative complications (Table 3). 


\section{Stimulation amplitude, pulse width, and battery consumption}

Stimulation amplitude and pulse width were lower in STN DBS than in GPi DBS, which correlates to low battery consumption [3] and allows longer time intervals between pulse generator replacements. This decreases both the cost and the risk during surgical replacement of pulse generators [4].

\section{Conclusions}

Current evidence suggests that there is no significant difference between STN DBS and GPi DBS in terms of motor improvement on the UPDRS III score although STN DBS allows more reduction in antiparkinsonian medication. STN DBS was associated with more decline in verbal fluency when compared to GPi DBS. Additionally, neuropsychological performance was slightly affected after STN DBS compared to GPi DBS. These findings suggest that the selection of surgical target in PD patients should be done on an individual basis according to patient status and preferences. In patients who are at risk of neuropsychological deterioration and those with speech problems, GPi DBS is a favorable target in order to avoid the possible neuropsychological problems following STN DBS. On the other hand, STN DBS is a favorable surgical target for patients who are not tolerating high doses of levodopa; those patients will take the advantage of medication reductions with STN DBS. In addition, the less battery consumption and the long intervals between pulse generator replacements in case of STN DBS make it a better target from an economic point of view.

\section{Additional Information \\ Disclosures}

Conflicts of interest: In compliance with the ICMJE uniform disclosure form, all authors declare the following: Payment/services info: All authors have declared that no financial support was received from any organization for the submitted work. Financial relationships: All authors have declared that they have no financial relationships at present or within the previous three years with any organizations that might have an interest in the submitted work. Other relationships: All authors have declared that there are no other relationships or activities that could appear to have influenced the submitted work.

\section{References}

1. Bronstein JM, Tagliati M, Alterman RL, et al.: Deep brain stimulation for Parkinson disease: an expert consensus and review of key issues. Arch Neurol. 2011, 68:165.

10.1001/archneurol.2010.260

2. St George RJ, Carlson-Kuhta P, Nutt JG, Hogarth P, Burchiel KJ, Horak FB: The effect of deep brain stimulation randomized by site on balance in Parkinson's disease. Mov Disord. 2014, 29:949-953.

3. Odekerken VJJ, van Laar T, Staal MJ, et al.: Subthalamic nucleus versus globus pallidus bilateral deep brain stimulation for advanced Parkinson's disease (NSTAPS study): a randomised controlled trial. Lancet Neurol. 2013, 12:37-44. 10.1016/S1474-4422(12)70264-8

4. Follett KA, Weaver FM, Stern M, et al.: Pallidal versus subthalamic deep-brain stimulation for Parkinson's disease. N Engl J Med. 2010, 362:2077-2091. 10.1056/NEJMoa0907083

5. Jones HN, Kendall DL, Okun MS, et al.: Speech motor program maintenance, but not switching, is enhanced by left-hemispheric deep brain stimulation in Parkinson's disease. Int J Speech Lang Pathol. 2010, 12:385-398. 10.3109/17549507.2010.491870

6. Okun MS, Fernandez HH, Wu SS, et al.: Cognition and mood in Parkinson's disease in subthalamic nucleus versus globus pallidus interna deep brain stimulation: the COMPARE trial. Ann Neurol. 2009, 65:586-595.

7. Rothlind JC, Cockshott RW, Starr PA, Marks WJ: Neuropsychological performance following staged bilateral pallidal or subthalamic nucleus deep brain stimulation for Parkinson's disease. 
J Int Neuropsychol Soc. 2007, 13:68-79. 10.1017/\$1355617707070105

8. Nakamura K, Christine CW, Starr PA, Marks WJ: Effects of unilateral subthalamic and pallidal deep brain stimulation on fine motor functions in Parkinson's disease. Mov Disord. 2007, 22:619-626.

9. Anderson VC, Burchiel KJ, Hogarth P, Favre J, Hammerstad JP: Pallidal vs subthalamic nucleus deep brain stimulation in Parkinson disease. Arch Neurol. 2005, 62:554-560.

10.1001/archneur.62.4.554

10. Burchiel KJK, Anderson VCV, Favre J, Hammerstad JP: Comparison of pallidal and subthalamic nucleus deep brain stimulation for advanced Parkinson's disease: results of a randomized, blinded pilot study. Neurosurgery. 1999, 45:1375-1384. 10.1097/00006123199912000-00024

11. Katz M, Luciano MS, Carlson K, et al.: Differential effects of deep brain stimulation target on motor subtypes in Parkinson's disease. Ann Neurol. 2015, 77:710-719.

12. Odekerken VIJ, Boel JA, Geurtsen GJ, et al.: Neuropsychological outcome after deep brain stimulation for Parkinson disease. Neurology. 2015, 84:1355-1361.

10.1212/WNL.0000000000001419

13. Rothlind JC, York MK, Carlson K, et al.: Neuropsychological changes following deep brain stimulation surgery for Parkinson's disease: comparisons of treatment at pallidal and subthalamic targets versus best medical therapy. Neurol Neurosurg Psychiatry. 2015, 86:622629. 10.1136/jnnp-2014-308119

14. Weaver FM, Follett K, Stern M, et al.: Bilateral deep brain stimulation vs best medical therapy for patients with advanced Parkinson disease: a randomized controlled trial. Jama. 2009, 301:63-73. 10.1001/jama.2008.929

15. Weintraub D, Duda JE, Carlson K, et al.: Suicide ideation and behaviours after STN and GPi DBS surgery for Parkinson's disease: results from a randomised, controlled trial. J Neurol Neurosurg Psychiatry. 2013, 84:10.1136/jnnp-2012-304396

16. Dietz J, Noecker AM, McIntyre CC, et al.: Stimulation region within the globus pallidus does not affect verbal fluency performance. Brain Stimul. 2013, 6:248-253.

10.1016/j.brs.2012.05.011

17. Mikos A, Bowers D, Noecker A, et al.: Patient-specific analysis of the relationship between the volume of tissue activated during DBS and verbal fluency. Neuroimage. 2011, 54:S238-S246. 10.1016/j.neuroimage.2010.03.068

18. Rocchi L, Carlson-Kuhta P, Chiari L, Burchiel KJ, Hogarth P, Horak FB: Effects of deep brain stimulation in the subthalamic nucleus or globus pallidus internus on step initiation in Parkinson disease: laboratory investigation. J Neurosurg. 2012, 117:1141-1149.

10.3171/2012.8.JNS112006

19. Weaver FM, Follett KA, Stern M, et al.: Randomized trial of deep brain stimulation for Parkinson disease: thirty-six-month outcomes. Neurology. 2012, 79:55-65. 10.1212/WNL.0b013e31825dcdc1

20. Locke MC, Wu SS, Foote KD, et al.: Weight changes in subthalamic nucleus vs globus pallidus internus deep brain stimulation: results from the COMPARE Parkinson disease deep brain stimulation cohort. Neurosurgery. 2011, 68:1233-1238. 10.1227/NEU.0b013e31820b52c5

21. Robertson LT, St George RJ, Carlson-Kuhta P, Hogarth P, Burchiel KJ, Horak FB: Site of deep brain stimulation and jaw velocity in Parkinson disease. J Neurosurg. 2011, 115:985-994. 10.3171/2011.7.JNS102173

22. Taba HA, Wu SS, Foote KD, et al.: A closer look at unilateral versus bilateral deep brain stimulation: results of the National Institutes of Health COMPARE cohort. J Neurosurg. 2010, 113:1224-1229. 10.3171/2010.8.JNS10312

23. Zahodne LB, Okun MS, Foote KD, et al.: Greater improvement in quality of life following unilateral deep brain stimulation surgery in the globus pallidus as compared to the subthalamic nucleus. J Neurol. 2009, 256:1321-1329. 10.1007/s00415-009-5121-7

24. Rocchi L, Chiari L, Cappello A, Gross A, Horak FB: Comparison between subthalamic nucleus and globus pallidus internus stimulation for postural performance in Parkinson's disease. Gait Posture. 2004, 19:172-183. 10.1016/S0966-6362(03)00059-6

25. Sako W, Miyazaki Y, Izumi Y, Kaji R: Which target is best for patients with Parkinson9s disease? A meta-analysis of pallidal and subthalamic stimulation. J Neurol Neurosurg Psychiatry. 2009, 85:982-986. 10.1136/jnnp-2013-306090

26. Liu Y, Li W, Tan C, et al.: Meta-analysis comparing deep brain stimulation of the globus 
pallidus and subthalamic nucleus to treat advanced Parkinson disease: a review. J Neurosurg. 2014, 121:709-718. 10.3171/2014.4.JNS131711

27. Arnaout M, Negida A, El Ashal G, Fouda S, Ghanem E, El Ghonemy S: Meta-analysis comparing subthalamic and pallidal deep brain stimulation for patients with Parkinson's disease. Int J Surg. 2015, 23: S78. 10.1016/j.ijsu.2015.07.349

28. Elgebaly A, Elfil M, Attia A, Magdy M, Negida A: Neuropsychological performance changes following subthalamic versus pallidal deep brain stimulation in Parkinson's disease: a systematic review and metaanalysis. CNS Spectr. 2017, 1: 14. 10.1017/S1092852917000062

29. Negida A, Arnaout M, El Ashal G, Fouda S, Ghanem E, El Ghonemy S: Meta-analysis of mortality following subthalamic and pallidal deep brain stimulation for patients with Parkinson's disease. Int J Surg. 2015, 23:S25. 10.1016/j.ijsu.2015.07.070

30. Moro E, Lozano AM, Pollak P, et al.: Long-term results of a multicenter study on subthalamic and pallidal stimulation in Parkinson's disease. Mov Disord. 2010, 25:578-86.

31. Barcia-Salorio JL, Roldan P, Talamantes F, Pascual-Leone A: Electrical inhibition of basal ganglia nuclei in Parkinson's disease: long-term results. Stereotact Funct Neurosurg. 1999, 72:202-207. 10.1159/000029727

32. Ghika J, Villemure J-G, Fankhauser H, Favre J, Assal G, Ghika-Schmid F: Efficiency and safety of bilateral contemporaneous pallidal stimulation (deep brain stimulation) in levodoparesponsive patients with Parkinson's disease with severe motor fluctuations: a 2-year followup review. J Neurosurg. 1998, 89:713-718. 10.3171/jns.1998.89.5.0713

33. Krause M, Fogel W, Heck A, et al.: Deep brain stimulation for the treatment of Parkinson's disease: subthalamic nucleus versus globus pallidus internus. J Neurol Neurosurg Psychiatry. 2001, 70:464-470. 10.1136/jnnp.70.4.464

34. Weaver F, Follett K, Hur K, Ippolito D, Stern M: Deep brain stimulation in Parkinson disease: a metaanalysis of patient outcomes. J Neurosurg. 2005, 103:956-967. 10.3171/jns.2005.103.6.0956

35. Wojtecki L, Timmermann L, Jörgens S, et al.: Frequency-dependent reciprocal modulation of verbal fluency and motor functions in subthalamic deep brain stimulation. Arch Neurol. 2006, 63:1273-1276. 10.1001/archneur.63.9.1273

36. Bejjani BP, Houeto JL, Hariz M, et al.: Aggressive behavior induced by intraoperative stimulation in the triangle of Sano. Neurology. 2002, 59:1425-1427. 10.1212/01.WNL.0000031428.31861.23

37. Sensi M, Eleopra R, Cavallo MA, et al.: Explosive-aggressive behavior related to bilateral subthalamic stimulation. Parkinsonism Relat Disord. 2004, 10:247-251. 10.1016/j.parkreldis.2004.01.007

38. Frank MJ, Samanta J, Moustafa AA, Sherman SJ: Hold your horses: impulsivity, deep brain stimulation, and medication in parkinsonism. Science. 2007, 318:1309-1312.

10.1126/science.1146157

39. Fenoy AJ, Simpson RK Jr: Risks of common complications in deep brain stimulation surgery: management and avoidance. J Neurosurg. 2014, 120:132-139. 10.3171/2013.10.JNS131225

40. Kenney C, Simpson R, Hunter C, Ondo W, Almaguer M, Davidson A, Jankovic J: Short-term and long-term safety of deep brain stimulation in the treatment of movement disorders. J Neurosurg. 2007, 106:621-625.

41. Lyons KE, Wilkinson SB, Overman J, Pahwa R: Surgical and hardware complications of subthalamic stimulation: a series of 160 procedures. Neurology. 2004, 63:612-616.

10.1212/01.WNL.0000134650.91974.1A

42. Obeso JA, Guridi J, Rodriguez-Oroz MC, et al.: Deep-brain stimulation of the subthalamic nucleus or the pars interna of the globus pallidus in Parkinson's disease. N Engl J Med. 2001, 345:956-963. 10.1056/NEJMoa000827

43. Couto MI, Monteiro A, Oliveira A, Lunet N, Massano J: Depression and anxiety following deep brain stimulation in Parkinson's disease: systematic review and meta-analysis. Acta Med Port. 2014, 27:372-382. 